\title{
6 Russia's Central Asia: Photographic Symbology of Nationhood
}

\section{Histories}

With the popularization of photography, the medium's role in cultural and natural history followed new directions that reflected the ways in which imperial colonial science was being transformed. Ranging from landscape to portraiture, photography became a focus for various intellectual and crosscultural encounters and thus not only presented an extraordinary new visual technology but also introduced a new means of discourse between individuals, institutions, and audiences in different parts of the Russian Empire and across the globe. Photography took place under the Western influences in Russia, but swiftly found its own form. Russian peculiarities concerning the principles of empiricism, observation, and analysis, the whole Russian way of thinking about modernization, be it in medicine, mechanics, or education, were not always guided by ideas of efficiency and progress, nor were they always optimistic. Photography set the scene for engagement - at least twodimensionally - between the different ethnographic groups, disregarding conventional faith-based partitions. This process was carefully calibrated. By alternating between imperial and colonial structures, this research examines the intricacies of these relationships and offers a new perspective on photography's indispensable but complex role in Russian imperial history and the 19th-century colonial exhibitions in which photography was a significant component.

The comparative analysis that frames this study highlights the way nationalism in the Russian colonial era used the merging medium of photography alongside, but gradually also in place of, other forms of visual culture - to enhance imperial and global networks, support their investigations, advance their careers, and promote exhibitions and their history in novel ways for a new generation of consumers.

Perceiving nationalism through photography asks these various visual arguments about a shared classical "national" past that came to be challenged by or revised in modernist thought. It considers how photography has governed the field of Central Asian media and the media of exhibitions, shaping how these objects and images were collected, displayed, and circulated. 
Since Edward Said's (1935-2003) seminal book Orientalism, ${ }^{1}$ scholars have incorporated the transnational tool in colonial studies, but not to the extent it deserves. At a time when scholars across the humanities are embracing a "global turn," it is important to reassess colonial studies and consider new approaches that allow us to move beyond Euro- and Russo-centrism and simple explanations of "shared" tastes.

The Russian intrusion in Central Asia - unlike the British in India - was an armed invasion by Russia; the British had been in India as inconsequential traders since the beginning of the 17 th century. ${ }^{2}$ Central Asia remained a relatively unknown area of land and largely unfamiliar politics for the Russians until Emperor Alexander II (1818-1881) ordered it to be explored by force. ${ }^{3}$ Within the Turkestan domain (ILL), the more important areas still remained outside Russian control by

1 Edward W. Said, Orientalism (New York: Pantheon Books, 1978).

2 Only in the middle of the 18th century, when conditions in Bengal, the center of the East India Company's trading activities, began to change, was political intervention possible.

3 The shifting meaning of "law and order" in 19th-century Russian imperial policies can be seen in the history of the Russian colonial conquest of Central Asia through myriad small measures that brought "modern principles" into the Muslim world. Embracing the ideas of the 19th-century Enlightenment all together, themes of Muslim resistance and involvement with Imperial Russian rule have long defined the historiography of Russia and Central Asia. Among the authors whose writings raise many questions about the rich and complex history of the late 19th century Russian colonial relationship - rooted in the classic mistrust of empire - are thinkers as diverse as George Curzon (Russia in Central Asia in 1889 and the Anglo-Russian Question, 1889), Petr I. Pashino (Turkestansky Krai v 1866 godu, 1860), Eugene Schuyler (Turkestan: notes of a Journey in Russian Turkestan, 1877), and Mikhail A. Terentiev (Istoriia zavoevaniia Srednei Azii, 1906), none of whom was a xenophobic nationalist. More recent works locate the origins of this anti-imperial tradition in the aftermath of the Great Game and argue for its continued relevance to public life today. See Nathaniel Knight, “Grigor’ev in Orenburg, 1851-1862: Russian Orientalism in the Service of Empire?” Slavic Review 59, no. 1 (1998): 74-100; Mark Bassin, "Russia between Europe and Asia: The Ideological Construction of Geographical Space," Slavic Review 50, no. 1 (2003): 1-17; Robert P. Geraci, Window on the East: National and Imperial Identities in Late Tsarist Russia (Ithaca, NY: Cornell University Press, 2001); Aleksey Miller, Imperiya Romanovykh i Nazionalism. Esse po metodologii Istoricheskogo Issledovaniya [The Romanov's Empire and Nationalism. Essay on Historical Research Methodology] (Moscow: NLO, 2010); Jeff Sahadeo, Russian Colonial Society in Tashkent (1865-1923) (Bloomington, IN: Indiana University Press, 2007); David Mackenzie, "Expansion in Central Asia: St. Petersburg vs. the Turkestan Generals (1863-1866)," Canadian-American Slavic Studies 3, no. 2 (1969): 286-311; Robert D. Crews, The Prophet and the Tsar: Islam and Empire in Russia and Central Asia (Cambridge, MA: Harvard University Press, 2009); D. Yu. Arapov, “'Neobkhodimo . . . zanyat’sya obrazovaniem kraya' (Sattarkhan Abdulgafarov o zadachakh russkoi politiki v Srednei Azii” ['It is necessary . . . to improve education in the region' (Sattar-khan Abdulgafarov about the tasks of Russia's policy in Central Asia], Vestnik Evrazii [Bulletin of Eurasia] 1: 169-184. 
the late 1860s. This was the domain of Zaravshansk and Semirechie, the Khiva, the great plain between the steppes and the deserts, watered by the Aral Sea and its tributaries. The conquest of Khiva in 1873 marked an important stage for Russian rule in Turkestan. Khiva, Bukhara, and Samarkand, the great centers of Asiatic power, retained their political and commercial dominance throughout the 19th century, but a swing in interest and concern took place after 1865. It is not accidental that most of the photographs of Turkestan discussed here are from these parts. The Silk Road's physical landscape, theological impact, and cultural traits were, to a very remarkable degree, synonymous in the Western and Russian imagination with Central Asia. This focus changed after 1865 when Colonel Mikhail Cherniyaev (1828-1898) took Tashkent, and it replaced the Samarkand-BukharaKhiva triangle as the primary source of Russian power over Turkestan. The 19th-century colonies were not closed entities but were reliant on the movement of people and geography, their power being dependent on their relationships with other colonies and states. In 19th-century Russia, increased exploration fuelled fierce competition over the control of trade routes and territories and inevitably led to diplomatic entanglements that spanned from the Crimea to Central Asia and Siberia. These entanglements brought about hostile relationships, confusion, and admiration, giving rise to cross-cultural transfer, exchange, and friction as objects, practices, and people moved via trade and diplomacy. This contribution examines colonial encounters during the Russian rule in Central Asia to consider the following questions:

- How were colonial spaces adapted and transformed into national ones through the movement of material things such as photographs?

- Which particular aspects of nationalism and its political, social, and economic infrastructures enabled the exchange of photographic practices?

- To what extent do new nationalist methodologies and approaches need to be developed to consider Russian Central Asia within a global geopolitical network?

- How did such a vast and backward landmass as Central Asia, where the Russians were themselves no more than a large minority, manage to survive for so long under Russian rule? In other words, does national politics present a cogent and persuasive explanation for the Russian Empire's relative stability in its Muslim territories during the 19th century?

The focus of this contribution is fundamentally interdisciplinary: art historical, historiographic, architectural, literary, and religious spaces are the subjects of inquiry, not as discrete or separate entities, but as ones which overlapped, came into contact with one another, and at times into conflict with one another too. 


\section{Early Photographic Training, the Distribution of Photographic Prints and the National Media}

Considering the drastic changes in the technologies and practices of communication that characterized the 19th century - such as the introduction of electric telegraphy and the development of the railway and the postal system - in relation to and in conjunction with the contemporary emergence of photography, artists and photographers might have had less interest in theoretical explorations and more in practical developments in photography, a business that could serve them well during their travels. Many if not all technical officers of government services in Russian Turkestan were aware of its historical situation. From the beginning of their travels into Russia's Muslim territories, ${ }^{4}$ imperial authorities not only made significant efforts to integrate them into the existing routine but often actively employed their curiosity. During the late 19th century, for about sixty years, Central Asian photography was mainly in European and Russian hands. Slowly, members of other ethnic groups and locals moved into the fields, first as translators to the Russians, then as assistants, and a few made it as professional photographers to make money from the business and enjoy the fruits of the industry.

By the 1870s, the St. Petersburg photographic market had developed transEuropean relationships, and the photographic catalogs' entries expanded to reflect the training, provenance, and awards garnered by foreign photographers and patent holders, recent photographic processes, and the extended dealers' network. Russian photographic schools lacked the complex system of training of European establishments. Collectors bought primarily through dealers acting as intermediaries who facilitated cultural transfers. Stephen Greenblatt termed these intermediaries "mobilizers." ${ }^{5}$ Their photographic perspectives arose from a

4 The khanates of Bukhara, Kokand, and Khiva formed the territory of Central Asia at the time of the Russian conquest that started with conquering Tashkent (1865) and the formation of the Russian Turkestan Government-General (1867) that was officially renamed as the region of Turkestan in 1886. Its borders touched the Ust-Yurt plateau in the west, Jungar Ala-Tau, Pamir, and Tian-Shan in the east, the Khorasan Mountains in the south, and Targobatau and the AralIrtysh waterline in the north. These borders are drawn according to V.I. Mushketov's report (1886), confirmed in Vladimir I. Masal'sky, Polnoe geograficheskoe opisanie nashego otechestva: Nastol'naya i dorozhnaya kniga dlia russkikh liudei [A Complete Geographical Description of Our Fatherland. Table and Road Book for the Russian People], vol. XIX, Turkestanskii Krai (St. Petersburg: A.F. Devriena, 1913), 125.

5 Stephen Greenblatt, Cultural Mobility: A Manifesto (Cambridge: Cambridge University Press, 2010), 251. 
vision produced by an archipelago of new schools and national institutions in Tsarist Russia. This cultural and ideological infrastructure reproduced and disseminated new forms of knowledge, new regimes of "seeing," documenting, organizing, measuring, and categorizing the physical and metaphysical world. On the opposite side of the spectrum, the Department of Military Typography, Geodesy, and Cartography at the General Staff in St. Petersburg (founded 1825) immediately grasped the possibilities of the new medium, such as its scientific exactitude, reproducibility, and low cost. As functionaries of the Russian state and products of a new mode of military education - reinforcing the importance of statistics, modern sociology, technological and technical innovations, and political theory -, the officers from the Imperial Technical School succumbed to this very special order and embraced the regime. Russian colonial photography cannot be separated from this perspective. In those years, photographs, in order to be reproduced in maps, books, newspapers, and magazines, still had to be manually prepared. After only a few decades, the advances made in typographical techniques were such as to allow the photomechanical reproduction of the images on the same page as text. The continuous progress made in photographic procedures inside and outside technical institutions contributed to rendering this medium increasingly popular: this permitted obtaining images in a much quicker way and at much lower prices and costs than through other media.

Central Asia obviously immediately attracted a large number of photographers, often from the high military echelon, but not all of them were able to get there easily. Travel remained notoriously difficult, and the construction of the Trans-Caspian Railway, or the Russian Empire's "war railroad”6 (1880-1888), eased it only partially. The road connected the Caspian Sea to Samarkand but stopped short of the vast steppe up to Tashkent. Only in the 1890s, when the Anglo-Russian diplomatic relationship had rapidly deteriorated and the Andijan uprising took place in May 1898, did the urgent requests of the Minister of War, Aleksey Kuropatkin (1848-1925), reach the court in April 1899. An agreement was drawn up to continue the construction of this strategic railroad. ${ }^{7}$ Unlike Europe, whose colonial appetite was rewarded by tourists flowing into the

\footnotetext{
6 Winfried Baumgart, "Eisenbahn und Kriegsführung in der Geschichte," Technikgeschichte 38 (1971): 191-219.

7 Igor V. Lukoyanov, ed., Sooruzhenie Zheleznykh dorog v Srednei Azii i Persii [Construction of the Railroads in Central Asia and Persia] from Sergei Yu. Witte, Sobranie Sochinenii i dokumentalnykh Materialov [Collective Works and Documents], vol. I, book 2, part I (Moscow: Nauka, 2004), 413-417
} 
new countries in Africa and India, Central Asia has never become a tourist destination because of 1) the tremendous difficulties with traveling there; 2) matters of safety (riots and revolts made it unsafe for an adventurous traveler to move through the steppes and desserts), and 3) its languages, which posed natural boundaries, so one had to be equipped with a translator or know local tongues. ${ }^{8}$ Expeditions commissioned by national institutions - the Imperial Orthodox Palestine Society, the Imperial Russian Archeological Society, the Russian Geographical Society, the Society of the Amateurs of Anthropology, Ethnology, and Ethnography, and the first museums of national importance - did not always depend on the middlemen - missionaries, traders, and explorers - who had previously made the choices about whom to convert or what to collect, donate, or sell. Photographers observed and documented ethnographic groups, which were merged with expeditions' comprehensive reports on their fieldwork, and carefully documented the data collected and the connections made in the field. Both historical and more recent scholarship has examined the details of the fieldwork and national strategies of these scientific expeditions,

8 The shifting meaning of European supremacy in the Muslim world can be seen in the history of the long 19th century. In arguing their case, European Orientalists take their readers on a fascinating journey over the summits and through the valleys along the Islamic road to the modern world. One of the summits is the study of language, a vitally important subject, often considered in discussions of the modernization imposed on the "Russian" Muslims by reforming the education system. Persuaded or not of the necessity of studying the Russian language despite formidable religious opposition that was partly the result of the widespread Muslim belief that "who imitates another people becomes one of them" (as a proverb that reflects anxieties about loss of identity) - the Russians were hired by the Mullahs to improve the conversation skills of their subjects, knowing it was a dangerous undertaking. Dangers such as these seemed destructive due to the impact of the real transformations in social attitudes, such as the shift from acceptable to unacceptable, progressive to non-progressive. These ideas and actions were transferable, and they have also entered the Islamic one. They were at work during the Soviet era - even if they were sometimes rebuffed -, as the recent publication edited by Artemy Kalinovsky and Michael Kemper, Reassessing Orientalism, demonstrates: “Just as European romantic nationalisms also fed from the knowledge provided by local informants - for instance in the Baltics, where ethnic German folklorists relied on the data provided by Estonian collaborators - so also Soviet and Western Orientlogies incorporated 'Orientals,' first as providers of raw information but increasingly as colleagues; and just as the German folklorists paved the way for Baltic nationalisms, so also Muslim Orientalists from Central Asia used the system of Soviet Oriental studies to develop their own national agendas.” Artemy Kalinovsky and Michael Kemper, "Introduction: interlocking Orientologies in the Cold War era," in Reassessing Orientalism: Interlocking Orientologies during the Cold War, ed. Artemy Kalinovsky and Michael Kemper (London: Routledge, 2017), 12. 
conducted between 1860 and 1914, revealing the complexity of their work. ${ }^{9}$ Like the earlier expeditions, they sometimes overlapped with political, imperial, and commercial interests, but Russian colonial photography had always had an ideological edge. ${ }^{10}$

Karl Leberecht Immermann's (1796-1840) ironic comment on “staying home is the exception, now everyone travels at least five hundred miles a year, they travelled for travel's sake, to get away from the daily grind"11 fell on deaf ears. Turkestan was as distant and foreign to the Russians as it was dangerous. White supremacy movements - which are, ultimately, European supremacy movements have surged in Russian Turkestan. Yet, Central Asian photography debunks any notion of white supremacy or the inherent grandness of the European genome, or the Russian genome for that matter. Central Asia has always been at the crossroads of the world, a place where immigrant species from the Middle East, Africa, Asia, and Europe have converged, mingled, and hybridized, blending genome with genome to yield a bounty of new species that then colonized new lands. There was no notion of that dangerous concept of racial or genetic purity in Central Asia. This is particularly revealing in photography. Take the Turkestansky Al'bom (Turkestan Album, 1871-72), for example, the most formidable photographic production to commemorate the mighty Russian presence in Central Asia and produced for the opening of the great Polytechnic Exhibition in Moscow (1872), which featured a Turkestan section. The ethnographic section of the Turkestan Album demonstrates the range of people from the regions of Samarkand, Ura-Tyube, Khodzhent, and Tashkent and serves as a storytelling device, in slow motion, allowing Nikolai

\footnotetext{
9 Nikolai P. Ostroumov, Kolebaniya russkogo pravitelstva vo vzgliadakh na missionerskuy deyatelnost- Pravoslavnoj Ruskoi Cerkvi [Doubts of the Russian government over the missionary activities of the Russian Orthodox Church] (Kazan: Sotrudnik bratstva Sv. Guriya, 1910), 42; Nikolai P. Ostroumov, "Khrakteristika religiozno-pravoslavnoi zhizni musulman preimuschestvenno Srednei Azii," Pravoslavnoe Obozrenie 2 (June-July 1880); Nikolai P. Ostroumov, K Istorii narodnogo obrazovaniya $v$ Turkestanskom Krae, Lichnye vospominaniya (Tashkent, 1911); Nikolai P. Ostroumov, Konstantin von Kaufman, Lichnye Vospominaniya (1899). Three other accounts - a mix of archival material and anxious revision - may suffice: Paul W. Werth, At the Margins of Orthodoxy: Mission, Governance, and Confessional Politics (Ithaca, NY: Cornell University Press, 2002); Geraci, Window on the East; Robert P. Geraci and Michael Khodarkovsky, Of Religion and Empire: Missions, Conversion, and Tolerance in Tsarist Russia (Ithaca, NY: Cornell University Press, 2001).

10 Inessa Kouteinikova, "Tashkent in St. Petersburg: The Constructed Image of Central Asia in Russia's Nineteenth-Century Ethnographic Exhibitions," in A l'orientale: Collecting, Displaying and Approving Islamic Art and Architecture in the $19^{\text {th }}$ and Early $20^{\text {th }}$ Centuries (Leiden/Boston: Brill, 2019), 159.

11 Karl Leberecht Immermann, "The Wonders in the Spessart," in Tales from the German, Comprising Specimens from the Most Celebrated Authors, trans. John Oxenford and C. A. Reiling (London: Chapman and Hall, 1844).
} 
Nekhoroshev, the principal photographer for the Album whose photographic studio was based in Tashkent, to convey a tremendous amount of ethnographic information while maintaining a plot and point of view. Scenes are vividly, sensorily drawn. We come across over fifty nationalities and ethnic groups and are startled to realize how teeming and diverse Central Asia's "human fauna" used to be. These people are not caught busily going about their routine daily activities; they are carefully staged, posed, and presented as porcelain figures, arranged according to their function and degree of attractiveness. They were a different clientele, representing the new exotic Russia by offering themselves as ethnographic material. The photographs here are anything but neutral documents intended as memoranda.

The Turkestan Album probably remains the most fully chronological and veritable description of the colony. Thanks to Nekhoroshev's extraordinary eye, we own portraits of the locals and countless images of the ruins, festivities, and traditional rituals, coproduced by the profession of what can be considered as being the first insightful look into the lives of the colonized. From the 1870s, however, various amateur photographers such as the young explorer and naturalist Aleksey Fedchenko (1844-1873) produced photographs of the principal natural forms of the region. After one examination of his photographic valise, it is impossible to say that the ambiguities of Fedchenko's short life were never apparent in his photographic works and scientific descriptions. His images are examples of faithful documentation, often with clarity and an eager eye. Clearly, he was not trained as a photographer, for the point of view often appears dull, especially when it comes to depicting one unexpected delicate shape after another. They are both stark and lush, bewitching and expressionistic balances of leaves and flowers. His wife, Olga, assorted her own botanical drawings into albums, connecting her scientific work to the decorative art of her own time. Such gentle criticism could be extended to include many images made by Russian and European photographers - the Dane Ole Olufsen (1865-1929), the Swedish explorer Sven Hedin (1865-1952), the Finnish officer at the service of the Russian Empire, or Carl Gustaf Mannerheim (1867-1951), who learned photography at various technical and military schools - and, in situ, they could all be described as professionals working in Russian Central Asia, making art in the service of natural and political sciences, quite separate from contemporary aesthetic standards. Yet, they inextricably bound their names to the representation of colonial Turkestan in which the positivist spirit of cataloging often gives way to the taste for the exotic and the picturesque.

With the introduction of photography to Central Asia came the realization that the whole new world was waiting to be photographed. Others modeled their expeditions on the models of the European practices and grand tours, such as 
Aleksandr Komarov (1830-1904); Liubov (or Lidia, according to other sources) Poltoratzkaya, the wife of the Governor-General of Semipalatinsk, Aleksandr Poltoratzky; the professor of Persian studies Valentin Zhukovsky ${ }^{12}$ (1858-1918); the self-taught photographer, ethnographer and future curator Samuil Dudin (1868-1929); Grigori A. Pankratiev, ${ }^{13}$ the army captain serving in Samarkand between 1894 and 1904; Ivan Vvedensky, who was active in Samarkand between 1894-97; Grigori Krivtzov and Nikolai Bogaevsky (1840-1888), who also worked on the Turkestan Album hand in hand with Nekhoroshev and the gifted Orientalist Aleksey Kun (1843-1912); or V. F. Kozlovsky, who was active in Central Asia in the 1880s-1890s. Many of them had been trained as mobile photographers and moved from one project to another, gaining tremendous experience.

A great many people made photographs in the later 19th century Central Asia but few as vivid as Nekhoroshev's (ILL). What do we make of certain indigenous photographers who often quietly collaborated with the Russian natural scientists, orientalists and linguists, transforming traditional photographic reproductions of Central Asian objects into original creations. ${ }^{14}$ Of course, they all anticipate the Russian Court photographer Sergei Prokudin-Gorsky (1863-1944), the early Soviet scientific and documentary photography, but even more strongly they anticipate what happened when early 20th-century artists like Max Penson, Pavel Kuznetzov, Aleksandr Usto-Mumin (Nikolaev), Aleksandr Volkov, or Georgy Zelma rescued the expeditionary photography from the placid Imperial album. The connection to later experiments is especially suggestive in Nekhoroshev's work.

Where - apart from portraits, which were a given - should they begin? What objects were chosen to be photographed? What were the criteria for the colonial albums and the official photographic commissions? How precise did the information have to be? How positive a delivery of the photographic

12 Valentin Zhukovsky, Drevnosti Zakaspiiskogo Kraya Razvaliny Starogo Merva [Antiquities of the Trans-Caspian Region. Ruins of the Ancient Merv] (St. Petersburg: Tipografiya Glavnogo Upravleniya Udelov, 1894). See also Vasily Bartold, Pamiati Zhukovskogo, Sochineniya [In Memory of V.A. Zhukovsky. Selected Works], vol. 9 (Moscow: Izdatel'stvo Vostochnoi Literatury, 1977).

13 Pankratiev enjoyed the patronage of the Great Duke Nikolai Rostovtzev, whose generous stipend enabled Pankratiev to complete the photographic album on Samarkand antiquities with S.A. Lapin's translations from the Arabic inscriptions of the Samarkand mausoleums. All ten copies of the Album were published at "a good price”. See Turkestanskie Vedomosti (Tashkent, 1904), 140.

14 Many Turkestan expeditions and military campaigns have been instructed by leading Orientalists and scientific members of the Archeological Commissions to keep an eye on the antiquities. For example, the eminent Orientalist P.I. Lerkh gave instructions for the Khiva campaign (1873), outlining the priorities for looking for numismatic, archeological, and ethnographic artifacts and keeping them safe. 
documentation was expected by the Russian court? Could photographers be critical or neutral of their subjects and sitters? How effective was photography in documenting each object, emphasizing their value as cultural treasures, reflecting aspirations of the time? The possible modifications of contents and format that the colonial album encompassed could make for a complex mobility of meanings, from the publishers' presentation to an individual's collector's personal reconfigurations or additions.

The evocative literary sources (with considerably fewer images) called into question the fixity of the archaeological viewer and the primacy of the three-dimensional object (sculpture and ceramics) over the photograph that could record it. The fact that ancient Central Asian culture made groundbreaking achievements that brought contributions to mathematics, linguistics, astronomy, architecture, politics, military cultures, administration, and medicine was effectively praised by Oriental rationalists and colonialists, but the complexity of the early scientific assignments around the citadel of Afrasiab or other sources of antiquities in Samarkand defeated many great scientists, including Vasily (Wilhelm) Bartold (1869-1930). Neither the one nor the other complexity reduction does justice to Central Asian culture or any other culture, for that matter. This should be remembered not only by those that approach a culture from the outside but also by those who bear that culture within.

\section{Photography as National Media}

Several crucial steps took place in the first decade of the Russian campaign in Turkestan - the establishment of the propaganda apparatus, the introduction of the Cyrillic alphabet, the publication of the main titles of Russian literature. The Turkestan government insisted on publishing the educational stories by Aleksandr Pushkin (1799-1837) and Lev Tolstoy (1828-1910), and Niva (Field), the populistic Russian publication based in St. Petersburg, flourished by including the lowbrow reports of travels between Moscow and Tashkent and back and missives by Muslim children who described the "Russian customs and culture along the way" (1889). Some steps were done in reverse: the Tuzemnaya Gazeta (Local Newspaper), a Russian propaganda tool under Konstantin Petrovich von Kaufmann (1818-1882), the first governor-general of Turkestan, sent an order to bring in the Arabic alphabet and a group of leading specialists in the Arabic language to publish the newspaper in local languages. Based in Samarkand, the newspaper Okraina (Outskirts, published between 1890-98) praised the 
education of Uzbek women. In October 1881, the progressive colonel Nikolai Mayev took the position of editor of the major national forum, the Turkestanskie Vedomosti (Turkestan News) and, at around the same time, of the branch of the Russian Telegraph Agency in Tashkent. He inspired the first generations of Russian businessmen to go to Central Asia with his excellent guide written on the occasion of the first Tashkent Industrial Exhibition in 1890. Those novelties changed many things for many people.

In his book Russian Architecture: Trends in Nationalism and Modernism (1969), Arthur Voyce sums up the process of Russia's integration with European modernization processes as follows: "With the advance of the modern industrial era and the awakening of the Russian middle classes, an infiltration from Europe of an irrational Classicism and a sugary romanticism could be noted. To combat that sprang up there the Russian National School set itself against the cosmopolitan eclectic aestheticism of the upper classes." 15 While the European influence was significant, nationalism set the scene for a different kind of integration: "The Nationalists were seeking to revive the ancient traditions of Russian art and architecture and to put new life into the old forms by infusing them with the freshness, simplicity and the fantastic picturesqueness of the rustic Russian. It was because of this movement that the direction and the quality of the art of the city began to be seriously influenced by the primitive rural art, an art that had been developing through many centuries in the isolated quietness of the village and in the calm of the limitless steppes and forests." ${ }^{\text {"16 }}$ At a time when the Russian architects in Tashkent were persuaded of the necessity to turn the new capital of Russian Turkestan into Moscow, ${ }^{17}$ this message could not have been more relevant and urgent.

Russia was part of this new expectation to visualize the world through photography. However, the processes of modernization and globalizing forces unleashed by the Russian Empire led to an awkward juxtaposition. The Russian and Asiatic photographers who were at work in Russian Turkestan were under double pressure from the bullying mentality epitomized in the Russian authorities and the resistance of the local population. This suggests that Russians used the public display of colonial material to define themselves as a nation. They were able to do so because the organizers of such displays constructed them as protean events with numerous possible meanings, even as they used them to disseminate liberal ideas about Russian society, the economy, and Russia's

15 Arthur Voyce, Russian Architecture: Trends in Nationalism and Modernism (New York: Greenwood Press, 1969), 121-122.

16 Ibid., 23.

17 For a detailed account of Russian colonial life in Central Asia, see Sahadeo, Russian Colonial Society in Tashkent. 
relationship with Islam and the rest of the world. Russian Turkestan was actively and visibly a colony that was representative of many trends that were occurring throughout the Empire. Scholars such as Mark LeVine, Ali Behdad, and Stephen Sheehi have shown similar transformations in the Middle East. ${ }^{18}$ Colonial photographic histories in Russia remain unchartered and deserving of serious scholarly attention.

The aesthetics of photography, no less than those of the other arts, were affected by the general spirit of restlessness and discontent, and the swinging theoretical polemics between the older and younger schools of the profession contributed to rigorous debates between the reactionary and retrospective and the radical and provocative, breaking up the traditional patterns and rhetoric.

A wide range of cultural forms convey the 19th-century Russian fascination with unearthing and exposing - and also reanimating - the unseen and the unknown. It is no mere coincidence that the period in which Turkestan came to public light and attained its greatest prominence comprises those same decades that witnessed the rise of modern museums, in which the emergent historical sciences of geology, palaeontology, and archaeology were coming under the public gaze in an entirely unprecedented way. The representation of extinct species and little-known races held considerable significance for the prospects of colonial and ethnographic museums. Imperial collections, institutions for national interests, relied on a similar set of ideas.

\section{Defending Nationalism, Pursuing Internationalism: The Glory of Colonial Exhibitions}

World Fairs and international exhibitions were closely connected to nationalism. They were devised as peaceful contests of nations: from the very start in 1851, the Great Exhibition of spectacular works of industry offered each participating country its own section in London's Crystal Palace to show off its contribution to human progress. The focus on industrial products enabled the host country to emphasize its leading position. Four years later, the Parisian follow-up (the Exposition Universelle) added agriculture and fine arts, thus foregrounding

18 Mark LeVine, Karin van Nieuwkerk and Martin Stokes, eds., Islam and Popular Culture (Austin: University of Texas Press, 2016); Ali Behdad, "Orientalist Desire, Desire of the Orient," French Forum 15, no. 1 (1990): 37-51; Stephen Sheehi, Arab Imago: A Social History of Portrait Photography, 1860-1910 (Princeton, NJ: Princeton University Press: 2016). 
fields in which France excelled. Even so, machinery, agriculture, and fine arts offered scant grounds for distinguishing one country from its neighbors. Therefore, at the next Parisian World Fair in 1867, all participating countries were invited to erect a pavilion in a characteristically national style to exhibit their own "authentic" culture. World Fairs accordingly became global platforms where nations learned how to represent their identity in a favorable light. National pavilions in fact were instrumental for a tighter definition of national culture by exhibiting meaningful archaeological finds, important historical artifacts, and traditional costumes and typical artisanal products while also offering characteristic dishes and beverages.

The brand of the colonial and universal exhibitions relied on and drew its value from networks of social, political, and commercial alliances and relationships that were not singularly built but produced through selective energies that drew together individuals, communities, social groups, and institutions through the capital and periphery of each individual nation. Colonial exhibitions were battlegrounds in which different groups within the Russian imperial court, the Directorate of the General Staff, and the Societies for Archaeology, Antiquities, and Sciences fought to present their vision of what sort of nation Russia should be. To analyze the exhibits on display is to argue how inherently antithetical the commercial line was vis-à-vis culture and scientific explorations.

The second argument concerns the forms and directions of industrialization that Russia followed and why, and what would happen if it took a different path and adopted a different model, for example, the British or the French one. Can we insist that the Turkestan exhibition was designed to celebrate Russia's economic successes or to hide its deficiencies? Was it organized to locate the mistakes the colonial policies made alongside the process of conquest or to remedy them through the commercialization of the Fair? Whereas the organizers and many observers portrayed the exhibition as a tribute to a new socio-political order and religious and ethnographic integration, a more careful analysis of attendance patterns might disclose deep, underlying divisions. Did the Turkestan Fair work in reality to segregate the Russian and Asiatic parts of the city of Tashkent, not just by urban zones but on regional, occupational, ethnic, ${ }^{19}$ and gender bases as well $?^{20}$

19 As Jeffrey Auerbach suggests in his chapter on nationalism and internationalism, "in general, northern Europeans were held in the highest regard, followed by southern Europeans, with Russians, Asians, Africans, and American Indians bringing up the rear. Racial and ethnic groups that were perceived as exotic or different, and nations that were not Westernized or industrialized, were considered lowest in the hierarchy." Jeffrey A. Auerbach, The Great Exhibition of 1851: A Nation on Display (New Haven, CT/London: Yale University Press, 1999), 167.

20 Similar questions have been posed by Auerbach but for Victorian society and the British class division that viewed their closest neighbors as the exotic, foreign "other." Ibid., 3. 
The 1860s, when Feodor Dostoyevsky wrote Notes from Underground (1864) and Nikolai Chernyshevsky published his pamphlet novel What is to Be Done? (1863), were a watershed in Russian history, the decade during which Russia began to modernize. It had lost the Crimean War in 1857, which led to a number of reforms, not the least of which was the decision by the Tsar to free the serfs in 1861. The modernization process took longer than anyone expected. Dostoyevsky was both angry and defensive about the achievements of the West: "[I]t was simply inconsistent with the laws of nature." ${ }^{21} \mathrm{He}$ felt shame at his country's backwardness; the more impressive the achievement, the less Dostoyevsky was able to acknowledge it. What he was really reacting to, in Notes from Underground, was not the Western reality of modernization, which was full of conflict and debate, but the Russian fantasy of modernization as a means of silencing that very debate. Nor did all Russians view the Crystal Palace the way Dostoyevsky did. In 1859, Chernyshevsky made a brief visit to London and wrote in his prison work What Is to Be Done? about the Crystal Palace, which, for the heroine, appears like a magical vision in a dream, "a symbol of the new modes of freedom and happiness that Russians can enjoy if they make the great historical leap into modernity."22

The already famous Silk Road was also high on the agenda of the Imperial Russian Geographic Society and Archaeological Committee in St. Petersburg. The scientific organizations took the lead in setting out to photograph the world of Central Asia systematically. Many expeditions included artists. Vasily Vereshchagin (1842-1904, ILL) set himself an even greater task in covering the colonial campaign in Central Asia, not only because he joined the military campaign of the first governor of Turkestan (1867/68), but also because he took in Samarkand, Tashkent, and Khiva (second Turkestan trip, 1869/70) in addition to other itineraries, which he came back from with something like a thousand drawings and oil sketches. Vereshchagin, who had possibly been instructed in the photographic medium by one of von Kaufmann's officers, was a ruined minor aristocrat who possessed apparently few material possessions but huge personal and artistic ambitions. He always looked for ways to display or publish his art, using some artworks as references for his larger paintings, which he sent out into the world as a complete exhibition, often accompanying the dispatch. He failed to sell many, and most of his art remains in Russia up to this day. His fame is larger than his life, and his life is larger than his travels, which included Central Asia and the Caucasus, the Russian North and the Volga region, Cuba and the Philippines, North America, and India. He died as fearlessly as he lived, during the Russo-Japanese War (1904/05).

21 Feodor Dostoevsky, Notes from Underground (New York: Dover, 1992), 17, $23-25$. 22 Ibid., 26. 
He was a great documentary painter and probably a good photographer, a profession he denied, calling it a shameful activity for a good artist: "I'm blamed for using the camera for my paintings, but it's the opposite." ${ }^{23}$ As a battle painter, Vereshchagin was an old hand at shocking the public. In 1873, he had provoked St. Petersburg with his Turkestan series, entitled The Barbarians (ILL) and completed in Munich (1872/73), the necessary atmosphere being created by the atrocities of war between the Russian army and the locals. Terrifying backdrops with hundreds of scalps suggested the unknown depths of the human tragedy, while Vereshchagin's canvases, cleverly lit and composed, produced still air and cloudless skies: life was turned into death.

Vereshchagin invited the last of the doubters, the journalists and fellow artists, for a private visit to his Munich studio, a rare invitation from an artist whose ferocious temperament kept his friends and enemies at bay. Not unexpectedly, Russia did not take great pride in the native son who had contributed to the glory of the nation. On the contrary, the Russian government and the military authorities saw in his photographic canvases a great threat to their aggressive actions toward Turkistan's rulers. Vereshchagin depicted the chronology of the conquest while the Russian court was more interested in seeing the glorifying aspects of their deeds in the south. No one seemed to notice that Vereshchagin minimized the importance of the role played by his government in the development of the region.

His works encompass structures, ruins, cityscapes, and people - the subjects of his immensely powerful Turkestan series ${ }^{24}$ are exactly as imposing, finely wrought, and perhaps even as ancient as his pillars of the minarets of Samarkand. The dimensions of his paintings are enhanced by his frames, which he crafted himself. He was seldom content with a conventionally composed view of a building, or a genre scene, or a portrait. He regarded himself as a "true Russian," a national Russian artist whose duties dictated his righteous deeds. Such morality was seldom taken well even by Vereshchagin's strong supporters. Ivan Kramskoy (1837-1887), another great Russian realist and one of the founders of the Peredvizhniki group, attacked Vereshchagin for his bookish documentality instead of being a visionary storyteller, advising him to write down his experiences in a book, not on canvas. This is, perhaps, the highest praise to Vereshchagin as an unknown photographer, something he denied throughout his life. Vereshchagin was an artist rather than a historian, ethnographer, ethnologist, or journalist. His taste for

23 Vasily Vereshchagin, Listki Iz Zapisnoi Knizhki [Pages from the Artist's Note Book] (St. Petersburg: Tipigrafiya tov. I.K. Kushnerova, 1898), 150.

24 As per Vereshhchagin's intention, they were sold as a series to Pavel Tretiakov, the founder of the Tretiakov Gallery in Moscow, for 92,000 rubles. He later went so far as to build an extra building for Vereshchagin's works. 
battles and ruins and his interest in Islamic cultures were all predicated on Orientalist and colonial tendencies in those directions. He deplored the whitewashing peace scenes even though he was aware of their visual necessity because they destroyed the truth and merciless taste of reality. He was in every way a creature of his time, and yet he retained an open eye and an honesty about what he saw. He may have been drenched in preconceived notions of the Russian Academy of Arts, where he studied for a while, but his colonial portfolio does not suggest that it was bent or massaged to accord with an ideology. He preserved the chronicle of the Russian campaign as it stood in the more recent past, and, given how many others of his time have been destroyed or damaged, Vereshchagin's pictures are precious testimony in addition to being vigorous works of Russian national art.

The technique used for the negatives was the dry gelatine process; it would take at least half an hour to shoot the picture and develop each glass negative. Which other techniques were available to photographers? Did he share the process with anyone else? Did he employ an assistant or a team of assistants? Vereshchagin denies it. What was his sole purpose in photography? To officially establish his name as an international photographer, to move elsewhere from the inherited business of his father. Was he interested in witnessing the aftermath of the conquest, in becoming a chronicler and the oracle of the events passing before him? Did he want to live them full-heartedly or as a bystander? By the time he reached Central Asia, Vereshchagin had become quite active working under his own name.

Today, photographic scholars and researchers judge photographs as being artistic using a very different set of standards and which was not applicable in Vereshchagin's time. It was not until the advent of the compact camera and picture negatives that photographic societies, which reflect the Russian interest in the dispersion of the national message around the Empire and beyond, and photographers who had been stationed in or lived in Central Asia were ready to exploit all possible techniques of production. In keeping with the enthusiasm for photography, and later for film and video cameras as media to represent the colonies, the camera ceased to exist as a private tool or one adopted for private use.

Russia was increasingly busy creating the image of Central Asia to suit itself. $^{25}$ It was still an image intimately linked to the political and economic

25 A similar spectrum of questions has been posed by Christopher De Bellaigue about "the logic that lies behind such equivalences" in relation to the French idea of liberty and Islamic religious zeal, the tensions between the modern notions of equality and Islamic conceptions of justice, the adaptation of language and dress, etc. Christopher De Bellaigue, The Islamic Enlightenment: The Struggle Between Faith and Reason, 1798 to Modern Times (New York: Liveright: 2017). 
imperialism that Europe exerted over the rest of the world, one impregnated with exoticism and populated by steppes and deserts, Oriental bazaars, and Asian antiquities. Whether this was the Turkestan wisely governed by the Russian colonists as narrated by numerous Russian and Western European historians and Orientalists is debatable; however, it also should be observed to the detriment of a certain schematism that ends up taking the upper hand in the application of Edward Said's thesis that the very same notion of the Turkestan nation appropriated by the elements that were constructed out of the historical, linguistic and anthropological research carried out in the Russian, Asian, and Orientalist departments of universities, particularly German ones, where the first Russian professors of Orientalist studies worked and the respective languages were taught. Furthermore, from von Kaufmann to Vrevsky, the principal Turkestan governors were formed in the Russian military academies.

Russian colonial photography came into being and spread in less time than any technical process in colonial military history. It was only a few weeks after General Cherniaev's conquest of Tashkent that the first camera arrived in the region. The city did not see its first exhibition until 1887, but the presence of cameras in Tashkent left it dumbfounded. "So far, we have only seen the beginning of it," concluded the Turkestansky Vestnik, the leading newspaper of the time in Central Asia.

\section{Conclusion}

Colonial photography made for national importance gave feelings of preparation and control, the deliberate transformation of a shadowy circumstance of Russian history into a triumphant act of collecting scientific culture but also transmitting the national interests. Constructing the new image of Central Asia through photography was never so thorough a vice that its energy might not glorify the political deeds, even under the glare of public challenge and rebuke. The Russian conquest of Central Asia shows clearly how rapidly this became evident.

The nationalism of Turkestan had, in fact, little in common with the nationalism of European colonies. Its leaders spoke Russian, and many of them dressed in Russian clothes, but almost all of them came from those classes, especially in Samarkand, Bukhara, and Kokand, who had traditionally been the spokesmen and leaders within the fabric of Turkestan society.

In all the tangled history of the Turkestan subcontinent, nothing is more complex than this interweaving of the political achievement of the Russian and 
the creation of nation states. The process is almost certainly not yet completed, however, as was demonstrated in 1923 when the Bolsheviks concluded that such remnants of 19th-century liberalism as freedom of the press and unlimited access to the courts were working against the chief ends of the state - the preservation of law and order.

\section{Work Cited}

Arapov, D. Yu. “'Neobkhodimo . . . zanyat'sya obrazovaniem kraya’ (Sattar-khan Abdulgafarov o zadachakh russkoi politiki v Srednei Azii" ['It is necessary . . . to improve education in the region' (Sattar-khan Abdulgafarov about the tasks of Russia's policy in Central Asia]. Vestnik Evrazii [Bulletin of Eurasia] 1: 169-184.

Auerbach, Jeffrey A. The Great Exhibition of 1851, A Nation on Display. New Haven, CT/London: Yale University Press, 1999.

Bartold, Vasily. Pamiati Zhukovskogo, Sochineniya [In Memory of V.A. Zhukovsky. Selected Works], vol. 9. Moscow: Izdatel'stvo Vostochnoi Literatury, 1977.

Bassin, Mark. "Russia between Europe and Asia: The Ideological Construction of Geographical Space.” Slavic Review 50, no. 1 (2003): 1-17.

Baumgart, Winfried. “Eisenbahn und Kriegsführung in der Geschichte." Technikgeschichte 38 (1971): 191-219.

Behdad, Ali. “Orientalist Desire, Desire of the Orient.” French Forum 15, no. 1 (1990): 37-51.

Caraffa, Costanza and Tiziana Serena, eds. Photo Archives and the Idea of Nation. Berlin/ Munich/Boston: De Gruyter, 2015.

Crews, Robert D. The Prophet and the Tsar: Islam and Empire in Russia and Central Asia. Cambridge, MA: Harvard University Press, 2009.

De Bellaigue, Christopher. The Islamic Enlightenment: The Struggle Between Faith and Reason, 1898 to Modern Times. New York: Liveright: 2017.

Dostoevsky, Feodor. Notes from Underground. New York: Dover, 1992.

Fox-Amato, Matthew. Exposing Slavery, Photography, Human Bondage, and the Birth of Modern Visual Politics in America. Oxford: Oxford University Press, 2019.

Geraci, Robert P. and Michael Khodarkovsky, Of Religion and Empire: Missions, Conversion, and Tolerance in Tsarist Russia. Ithaca, NY: Cornell University Press, 2001.

Geraci, Robert P. Window on the East: National and imperial Identities in Late Tsarist Russia. Ithaca, NY/London: Cornell University Press, 2001.

Gies, Jacques, Michel Soymie, Jean-Pierre Drege, Danielle Eliasberg and Richard Scheneider, eds. Les Arts de l'Asie centrale, la collection Paul Pelliot du musee national des arts asiatiue, Guimet. 2 vols. Paris: Reunion des Musees Nationaus, 1994.

Greenblatt, Stephen. Cultural Mobility: A Manifesto. Cambridge: Cambridge University Press, 2010.

Immermann, Karl Leberecht. "The Wonders in the Spessart." In Tales from the German, Comprising Specimens from the Most Celebrated Authors, translated by John Oxenford and C. A. Reiling. London: Chapman and Hall, 1844. 
Kalinovsky, Artemy and Michael Kemper. "Introduction: interlocking Orientologies in the Cold War era." In Reassessing Orientalism: Interlocking Orientologies during the Cold War, edited by Artemy Kalinovsky and Michael Kemper, 1-15. London: Routledge, 2017.

Knight, Nathaniel. “Grigor'ev in Orenburg, 1851-1862: Russian Orientalism in the Service of Empire?" Slavic Review 59, no. 1 (1998): 74-100.

Kouteinikova, Inessa. "Tashkent in St. Petersburg: The Constructed Image of Central Asia in Russia's Nineteenth-Century Ethnographic Exhibitions." In A l'orientale: Collecting, Displaying and Approving Islamic Art and Architecture in the $19^{\text {th }}$ and Early $20^{\text {th }}$ Centuries. Leiden/Boston: Brill, 2019.

LeVine, Mark, Karin van Nieuwkerk and Martin Stokes, eds. Islam and Popular Culture. Austin: University of Texas Press, 2016.

Lukoyanov, Igor V., ed. Sooruzhenie Zheleznykh dorog v Srednei Azii i Persii [Construction of the Railroads in Central Asia and Persia] from Sergei Yu. Witte, Sobranie Sochinenii $i$ dokumentalnykh Materialov [Collective Works and Documents], vol. I, book 2, part I. Moscow: Nauka, 2004.

Mackenzie, David. "Expansion in Central Asia: St. Petersburg vs. the Turkestan Generals (1863-1866).” Canadian-American Slavic Studies 3, no. 2 (1969): 286-311.

Masal'sky, Vladimir I. Polnoe Geograficheskoe Opisanie Nashego Otechestva [The Complete Geographic Description of Our Fatherland], vol. XIX, Turkestanskii Krai. St. Petersburg: A.F. Devriena, 1913.

Miller, Aleksey. Imperiya Romanovykh i Nazionalism. Esse po metodologii Istoricheskogo Issledovaniya [The Romanov's Empire and Nationalism. Essay on Historical Research Methodology]. Moscow: NLO, 2010.

Ostroumov, Nikolai P. “Khrakteristika religiozno-pravoslavnoi zhizni musulman preimuschestvenno Srednei Azii.” Pravoslavnoe Obozrenie 2 (June-July 1880).

Ostroumov, Nikolai P. K Istorii narodnogo obrazovaniya v Turkestanskom Krae, Lichnye vospominaniya. Tashkent, 1911.

Ostroumov, Nikolai P. Kolebaniya russkogo pravitelstva vo vzgliadakh na missionerskuy deyatelnost- Pravoslavnoj Ruskoi Cerkvi [Doubts of the Russian government over the missionary activities of the Russian Orthodox Church]. Kazan: Sotrudnik bratstva Sv. Guriya, 1910.

Ostroumov, Nikolai P. Konstantin von Kaufman, Lichnye Vospominaniya. 1899.

Popov, A. Iz Istorii Zavoevaniya Srednei Azii. Istoricheskie Zapiski [From the History of Central Asian Conquest. Historical Notes]. Moscow, 1940.

Sahadeo, Jeff. Russian Colonial Society in Tashkent (1865-1923). Bloomington, IN: Indiana University Press, 2007.

Said, Edward W. Orientalism. New York: Pantheon Books, 1978.

Sheehi, Stephen. Arab Imago: A Social History of Portrait Photography, 1860-1910. Princeton, NJ: Princeton University Press: 2016.

Tashkenbaeva, D. “Formirovanie Osobennostei sredneaziatskikh geopoliicheskikh interesov Rossijskoi Imperiei" [Characteristical Formation of the Central Asian geopolitical interests by the Russian Empire]. Voprosy Istoricheskoi Nauki, Proceedings from the Third International Conference, Moscow, January 2015, 130-132. Moscow: Buki-Vedi, 2015.

Vereshchagin, Vasily. Listki lz Zapisnoi Knizhki [Pages from the Artist's Note Book]. St. Petersburg: Tipigrafiya tov. I.K. Kushnerova, 1898. 
Vitkind, Nikolai Ya. Bibliographia Po Sredney Asii. 1929.

Voyce, Arthur. Russian Architecture. Trends in Nationalism and Modernism. New York: Greenwood Press, 1969.

Werth, Paul W. At the Margins of Orthodoxy: Mission, Governance, and Confessional Politics. Ithaca, NY: Cornell University Press, 2002.

Zhukovsky, Valentin. Drevnosti Zakaspiiskogo Kraya Razvaliny Starogo Merva [Antiquities of the Trans-Caspian Region. Ruins of the Ancient Merv]. St. Petersburg: Tipografiya Glavnogo Upravleniya Udelov, 1894. 